\title{
Correction: Hemicrania continua- building on experience and clinical science
}

Peter J Goadsby ${ }^{1,2}$

\section{Correction}

The original version of this article [1] unfortunately listed the author's name as 'Peter J Goasdby'. The correct author name is Peter J Goadsby. The publisher would like to apologise to the author for this error and the inconvenience caused.

Received: 12 May 2014 Accepted: 12 May 2014

Published: 15 May 2014

\section{Reference}

1. Goadsby PJ (2014) Hemicrania continua- building on experience and clinical science. J Headache Pain 15:9

doi:10.1186/1129-2377-15-29

Cite this article as: Goadsby: Correction: Hemicrania continua- building on experience and clinical science. The Journal of Headache and Pain 2014 15:29.

Submit your manuscript to a SpringerOpen ${ }^{\odot}$ journal and benefit from:

- Convenient online submission

- Rigorous peer review

- Immediate publication on acceptance

- Open access: articles freely available online

- High visibility within the field

- Retaining the copyright to your article

Submit your next manuscript at $>$ springeropen.com

\section{Springer}

(C) 2014 Goadsby; licensee Springer. This is an Open Access article distributed under the terms of the Creative Commons Attribution License (http:/creativecommons.org/licenses/by/40), which permits unrestricted use distribution, and reproduction in any medium, provided the original work is properly credited. 